\title{
La poesía intimista de Anne Bradstreet
}

Fecha de recepción: 14 de marzo de 2007

Ángeles García CALDERÓN Universidad de Córdoba

Fecha de aceptación: 4 de mayo de 2007

Resumen: El trabajo analiza la obra de la primera poetisa de la literatura americana, que describe como se desarrolló la vida de los primeros peregrinos en la colonia de Nueva Inglaterra. Pionera, asimismo, en la descripción de una poesía interior desprovista de todo artificio, que con el paso de los siglos ha ido adquiriendo su verdadera dimensión en lo que concierne a autenticidad y pureza de sentimientos.

Palabras clave: Poesía inglesa, puritanismo, traducción.

Abstract: In this Article I analyze the works written by the first woman poet in American literature; this poetry describes how the first Pilgrims lives developed in New England: Anne Bradstreet was the first woman who wrote a poetry free of bounds; throughout the centuries her poetry would acquire its real dimension as far as authenticity and purity of feelings is concerned.

Key words: English poetry, Puritanism, Translation.

\section{INTRODUCCIÓN}

Anne Bradstreet (1612-1672) es una de las figuras más relevantes de la historia de la literatura norteamericana, y no sólo por ser considerada como la primera mujer poeta de ese país, o porque su obra The Tenth Muse Lately Sprung Up in America, By a Gentlewoman of Those Parts fuera el primer libro escrito por una mujer y publicado en los Estados Unidos, sino porque sus escritos son un documento de primera mano de las costumbres puritanas en la vida colonial de New England, así como de las condiciones sociales de las mujeres de su edad y su estatus en una nueva tierra. Sus poemas, dirigidos a menudo a su marido y a sus hijos, nacerán de la soledad a que se ve obligada por los continuos viajes de su esposo, el "Governor" Simon Bradstreet. A la vez que escribía, Anne enseñaba y educaba a sus hijos, llenando la ausencia del padre, con el mismo código moral, humilde y espiritual que utilizó durante toda su vida. Es curioso el hecho de que, a pesar de poseer una fe profunda (o al menos así lo han puesto de relieve sus biógrafos), la autora sienta una especial fascinación por los temas inherentes a la mente, al espíritu y al cuerpo, que llegan a ser para ella una especie de guía en constante y continua vigilancia.

Su estilo es en apariencia sencillo, aunque revela una mente de gran inteligencia e ideales plenamente realizada y con una fe basada en los 
acontecimientos cotidianos y las durezas de un clima absolutamente adverso, que pone de relieve un vocabulario rico, a pesar de su sencillez, y un conocimiento polivalente. Su poesía, realizada a través de pentámetros yámbicos, es eminentemente sencilla, clara y está basada en la observación de los valores tradicionales y cotidianos, por lo que guarda grandes semejanzas con la de otra relevante autora nacida en Amherst (Massachussets ${ }^{1}$ ), Emily Dickinson, así como con otro poeta que también viviera en Amherst ${ }^{2}$, Robert Frost. Es un tipo de poesía intimista que desde siempre se ha encontrado arraigada en la cultura de la gente sencilla, en sus sentimientos y fervores amorosos, reivindicando la belleza a través de la armonía, la serenidad y el reconocimiento del trabajo bien hecho, en cualquier situación, lugar o circunstancia; poética que tiene sus raíces en lo cotidiano, lo sencillo y nada grandilocuente, que adquiere a veces cotas sublimes en la descripción de todo lo aparentemente accesorio ${ }^{3}$. En la poesía de Anne Bradstreet el lector halla el germen de lo que luego desarrollarán otros autores ${ }^{4}$.

Es difícil una recensión de los trabajos de la escritora, aunque, por lo que concierne a las ediciones de sus obras lo más probable es que la primera edición completa sea la titulada The Works of Anne Bradstreet in Prose and verse, editada por John Harvard Ellis, Charlestown, Abram E. Cutter, 1867, y cuyo índice transcribimos 5 :

\footnotetext{
${ }^{1}$ Véase para este punto la obra de Wendy Martin: An American Triptych: Anne Bradstreet, Emily Dickinson, Adrienne Rich. Chapel Hill, University of North Carolina Press, 1984. Podemos hallar a veces grandes semejanzas respecto de la frecuencia de utilización de determinadas palabras; las más utilizadas por Dickinson son los monosílabos "día", "vida", "ojo", "sol", "hombre", y entre los sustantivos que utilizó cincuenta o más veces en su poesía, solamente "verano" y "mañana" son polisílabos en inglés.

${ }^{2}$ Poeta estadounidense considerado uno de los fundadores de la poesía moderna en su país, por expresar, con sencillez filosófica y profundidad sentimental, la vida y emociones del hombre rural de Nueva Inglaterra. La poesía de Robert Frost (1874-1963) refleja los impulsos más profundos del hombre norteamericano: su sencillez y amor por la naturaleza y lo rural, su individualismo, su ironía y humor revuelto con una gran soledad y tragedia; como en nuestra autora, en Frost el escenario de sus poemas más famosos suele ser el paisaje de Nueva Inglaterra.

${ }^{3}$ En este aspecto, podemos encontrar reminiscencias de la poesía de Bradstreet en Ralph Waldo Emerson (1803-1882) y su Trascendentalismo (modo de vida o filosofía que se fundamentaba en una vía intuitiva basada en la capacidad de la conciencia individual, sin necesidad de milagros, jerarquías religiosas ni mediaciones).

${ }^{4}$ Por ejemplo, la creencia de Wordsworth en que los niños y los pueblos no civilizados se encuentran más cercanos a Dios porque en ellos permanece la memoria del mundo celeste anterior al nacimiento.

${ }^{5}$ Por lo que respecta a las ediciones de sus poemas, la primera apareció en Londres en 1650 con el título de The Tenth Muse Lately Sprung up in America: Or Several Poems, Compiled with Great Variety of Wit and Learning, Full of Delight, 1650. La segunda edición se publica en Boston: Several Poems, Compiled with Great Variety of Wit and Learning, Full of Delight, John Foster (ed.),
} 


\section{CONTENTS}

Religious Experiences and Occasional Pieces

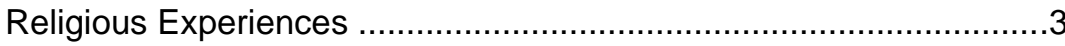

Occasional Meditations..............................................................

Deliverance from a Fever......................................................... 12

Deliverance from a Fit of Sickness...............................................13

Deliverance from a Fit of Fainting................................................15

Meditations on Spiritual Consolations ....................................16

Submission and Reliance on God, July 8,1656..............................17

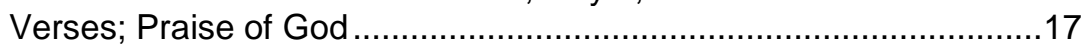

Verses; Joy in God............................................................18

After much Sickness, August 28, 1656 .............................20

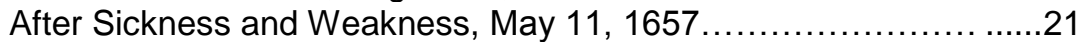

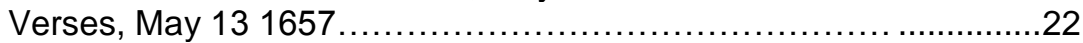

Submission to Chastisement from God, Sept. 30, $1657 \ldots \ldots \ldots \ldots \ldots . . .23$

Poem upon her son Samuel's going to England, Nov. 6, 1657 .........24

Divine Dealings, May 11, 1661..............................................25

Verses; Thankfulness for Health......................................26

On the Restoration of her Husband from an Ague, June, 1661 ........27

Upon her daughter, Hannah Wiggin's recovery from a Fever ...........28

On her son Samuel's return from England, July 17, 1661 .............28

On her Husband's going to England, Jan. 16, 1661-62 ...............32

In her solitary hours in her Husband's absence..........................34

In acknowledgment of the letters received from her Husband

in England

In thankful remembrance of her Husband's safe arrival

home, Sept. 3, 1662 ...........................................................38

Verses upon the burning of her house, Juli 10, $1666 \ldots \ldots \ldots \ldots \ldots \ldots \ldots . . . .40$

Verses; Longing for Heaven, Aug. 31, 1669 ...................................42

Meditations, Divine and Moral

Dedication of the Meditations to her son, Simon Bradstreet,

March 20, 1664 ............................................................................. 47

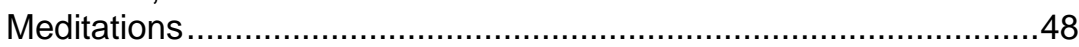

Latin Translation of the Dedication of the Meditations by her

great grandson Simon Bradstreet ................................................74

Latin Translation of the first four Meditations by the same ..................75

Boston, 1678. La tercera es una reedición de ésta última: Several Poems, Compiled with great Variety of Wit and Learning, full of Delight (Reprinted from the second Edition), 1758. 


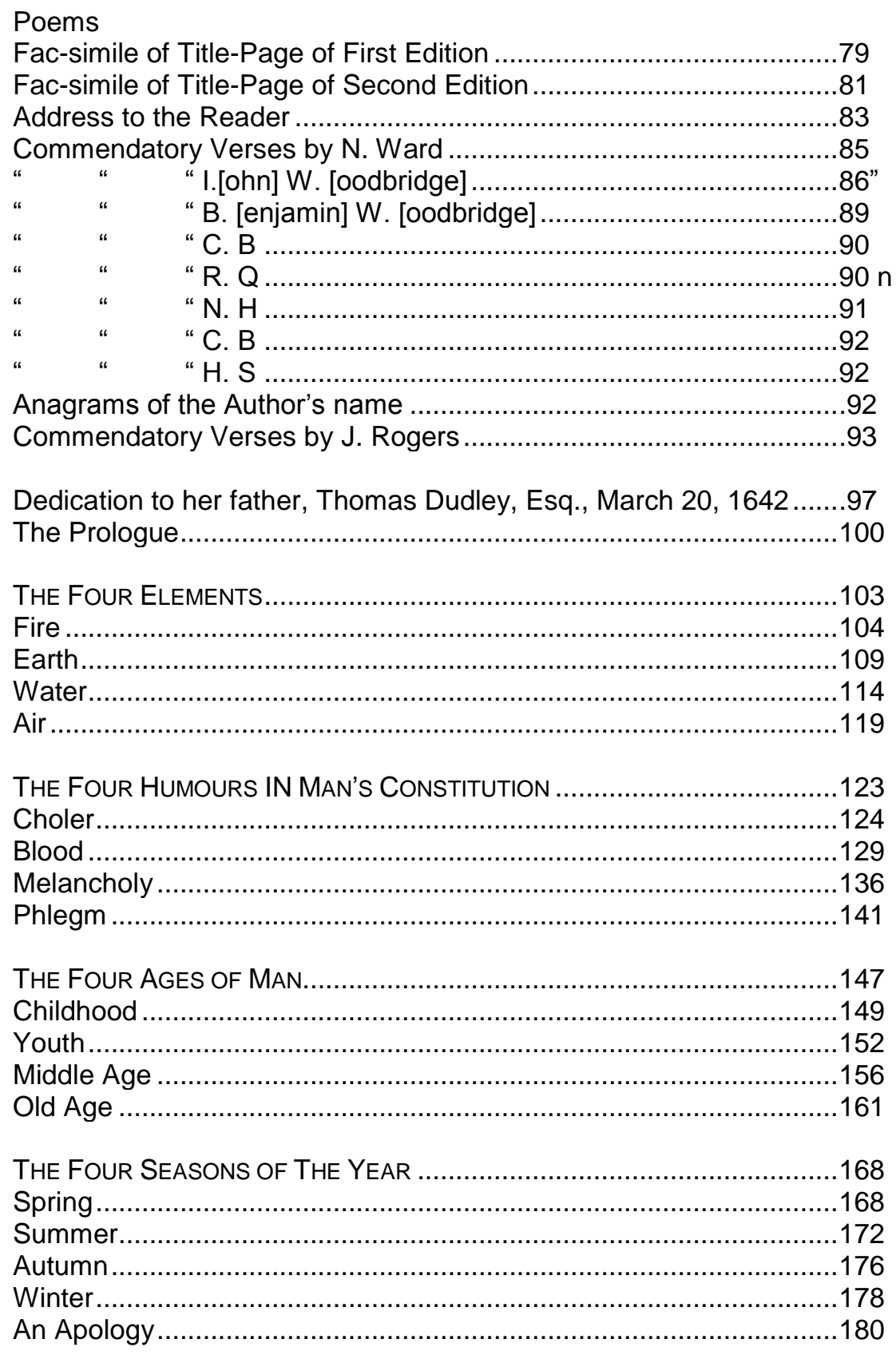


THE FOUR MONARCHIES........................................................... 181

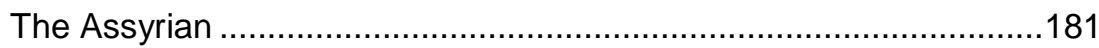

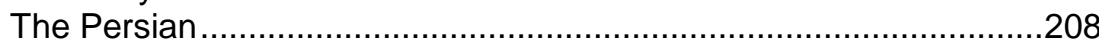

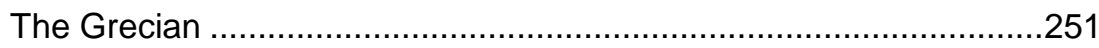

An Explanation ................................................................. 322

The Roman ...................................................................... 323

An Apology ....................................................................... 328

Dialogue between Old England and New; concerning their present troubles

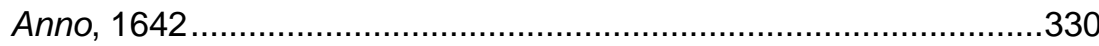

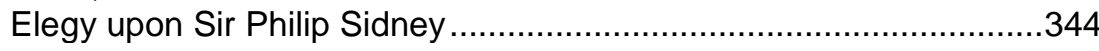

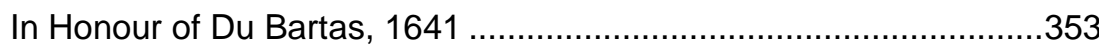

In Honour of Queen Elizabeth.......................................................357

David's Lamentation for Saul and Jonathan ...................................363

To the Memory of her Father, Thomas Dudley, Esq..............................365

Epitaph on her Mother, Mrs. Dorothy Dudley ..................................369

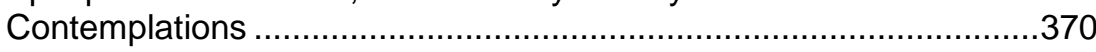

The Flesh and the Spirit.............................................................381

The Vanity of all Worldly Things ....................................................386

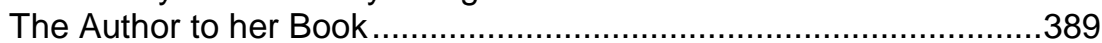

Posthumous Poems

Upon a Fit of Sickness, Anno 1632. AEtatis suæ, 19 .........................391

Upon some Distemper of Body ..........................................................392

Before the Birth of one of her Children ..........................................393

Verses to her Husband .............................................................394

Letter to her Husband, absent upon Public Employment .......................394

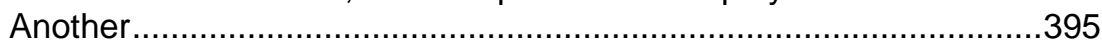

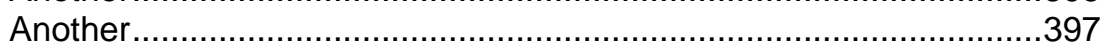

Th her Father with some Verses..................................................398

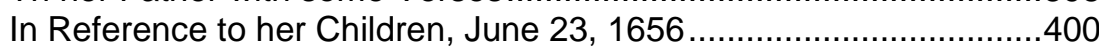

In Memory of her grand-child Elizabeht Bradstreet ...........................404

" " " " " Anne Bradstreet...................................405

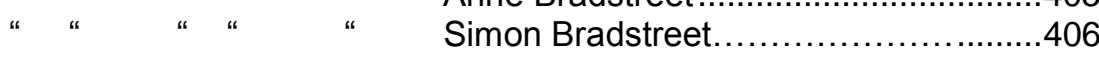

" " " " “ daughter-in-law

A Funeral Elegy upon the Author by the Rev. John Norton ................409 


\section{SELECCIÓN DE POEMAS EN VERSIÓN ORIGINAL Y TRADUCCIÓN AL ESPAÑOL 6}

A LetTer to Her Husband AbSent upon Public Employment My head, my heart, mine eyes, my life, nay more, My joy, my magazine, of earthly store, If two be one, as surely thou and I, How stayest thou there, whilst I at Ipswich lie? So many steps, head from the heart to sever, If but a neck, soon should we be together. I, like the Earth this season, mourn in black, My Sun is gone so far in's zodiac,

Whom whilst I 'joyed, nor storms, nor frost I felt, His warmth such fridged colds did cause to melt. My chilled limbs now numbed lie forlorn; Return; return, sweet Sol, from Capricorn; In this dead time, alas, what can I more Than view those fruits which through thy heart I bore? Which sweet contentment yield me for a space, True living pictures of their father's face.

O strange effect! now thou art southward gone, I weary grow the tedious day so long; But when thou northward to me shalt return, I wish my Sun may never set, but burn Within the Cancer of my glowing breast, The welcome house of him my dearest guest. Where ever, ever stay, and go not thence, Till nature's sad decree shall call thee hence; Flesh of thy flesh, bone of thy bone, I here, thou there, yet both but one.

\footnotetext{
${ }^{6}$ Los poemas seleccionados en este apartado son una muestra de los más representativos de la autora, característicos de su amor hacia su familia, de su pensamiento e inquietudes religiosas.
} 
CARTA A SU MARIDO AUSENTE POR DESEMPEÑO DE EMPLEO PÚBLICO Mi mente y corazón, ojos, vida y aun más, mi alegría, mis bienes del almacén terrenal, si dos fueran uno, ciertamente lo seríamos tú y yo, ¿cómo estás tú ahí, mientras yo estoy en Ipswich? Tantos pasos, para separar la cabeza del corazón, si por muy poco, pronto juntos estar debiéramos. Yo, al igual que la Tierra, esta estación estoy de luto, mi Sol se ha ido tan lejos en el Zodíaco:

mientras yo de él gozaba, ni tormentas ni hielo sentía, su calor derritió todos esos fríos gélidos.

Mis miembros congelados ahora entumecidos yacen solos;

regresa pronto; vuelve, dulce Sol de Capricornio;

en esta época de muerte, jay!, ¿qué puedo ver sino aquellos frutos que llevaba por tu corazón? Cuya dulce satisfacción me propició un tiempo, auténticas imágenes vivas de la cara de su padre. ¡Oh extraña sensación! Ahora que te has ido hacia el sur, siento el tedio crecer en mí al pasar los días; mas cuando vengas de regreso hacia el norte, ojalá que mi Sol nunca se ponga, sino que queme dentro, el Cáncer de mi pecho ardiente, la bienvenida casa de mi querido huésped.

Donde quiera que estés, quédate siempre, y de allí no te vayas, hasta que el triste decreto de Natura te llame; carne de tu carne, hueso de tu hueso, yo aquí, tú allí, pero los dos en uno. 


\section{A LOVE LETTER to HER HUSBAND}

Phoebus make haste, the day's too long, begone, The silent night's the fittest time for moan;

But stay this once, unto my suit give ear, And tell my griefs in either Hemisphere:

(And if the whirling of thy wheels do n't drown'd

The woful accents of my doleful sound),

If in thy swift career thou canst make stay,

I crave this boon, this errand by the way:

Commend me to the man more lov'd than life,

Show him the sorrows of his widow'd wife,

My dumpish thoughts, my groans, my brackish tears,

My sobs, my longing hopes, my doubting fears,

And, if he love, how can he there abide?

My interest's more than all the world beside.

He that can tell the stars or Ocean sand,

Or all the grass that in the meads do stand,

The leaves in th' woods, the hail or drops of rain,

Or in a cornfield number every grain,

Or every mote that in the sunshine hops,

May court my sighs and number all my drops.

Tell him, the countless steps that thou dost trace,

That once a day thy spouse thou mayst embrace;

And when thou canst not treat by loving mouth,

Thy rays afar, salute her from the south.

But for one month I see no day (poor soul)

Like those far situate under the pole,

Which day by day long wait for thy arise,

O how they joy when thou dost light the skies.

O Phoebus, hadst thou but thus long from thine

Restrain'd the beams of thy beloved shine,

At thy return, if so thou couldst or durst,

Behold a Chaos blacker than the first.

Tell him here's worse than a confused matter,

His little world's a fathom under water,

Naught but the fervor of his ardent beams

Hath power to dry the torrent of these streams.

Tell him I would say more, but cannot well,

Opressed minds abrupted tales do tell.

Now post with double speed, mark what I say,

By all our loves conjure him not to stay. 


\section{CARTA DE AMOR A SU MARIDO}

Febo corre raudo, el día es muy largo, se ha ido, el silencio nocturno es la hora mejor para la queja; mas quédate ahora, hasta que mi séquito preste oído $y$ cuente mis lamentos en ambos Hemisferios: (y si el constante giro de tus ruedas no cesa, el penoso acento de mis lamentos), si en tu rauda carrera no puedes quedarte, ansío esta ayuda, ese mensaje para el camino: envíame a un hombre más amado que la propia vida, muéstrale las penas de su viuda, mis tristes pensamientos, mis quejidos, mis abundantes lágrimas, mis sollozos, mis largas esperas, mis miedos llenos de dudas, y, si él quisiera, ¿cómo podría el vivir allí? Mi interés es mayor que todo el resto del mundo. Él, que hablar puede a las estrellas o a la arena del Océano, o a todas las plantas que en el prado crecen, a las hojas de los bosques, al granizo o a las gotas de lluvia, o a cada grano de maíz del maizal, o a cada mota de los rayos del sol, puede dar fe de todas mis miradas y enumerar todas mis lágrimas. Dile los incontables pasos de los que dejas huella, que una vez al día a tu esposa puedes abrazar; y cuando por amor no puedas soportar tus lejanos rayos, dale a ella la bienvenida desde el sur. Mas, durante un mes no veo el día (pobre alma) como en esos lugares situados bajo el polo, en los que día a día espero que aparezcas, oh, cómo se alegran cuando tú los cielos iluminas. ¡Oh Febo!, ¿durante largo tiempo ocultaste los rayos de tu amado brillo, a tu regreso?, si así pudieses o te atrevieses a contemplar un Caos más negro que el primero. Dile que aquí hay algo peor que una materia confusa, su pequeño mundo es una braza que se halla bajo el agua, y nada, sino el fervor de sus ardientes rayos, tiene poder para secar el torrente de estos arroyos. Dile que diría algo más, pero que no puedo, que las mentes oprimidas cuentos tortuosos contarán. Ahora envía esto rápidamente, escucha lo que digo, y por todos nuestros amores, conjúrale a que no se quede. 
THE AUTHOR TO HER BOOK

Thou ill-form'd offspring of my feeble brain,

Who after birth did'st by my side remain,

Till snatcht from thence by friends, less wise than true,

Who thee abroad expos'd to public view,

Made thee in rags, halting to th' press to trudge,

Where errors were not lessened (all may judge).

At thy return my blushing was not small,

My rambling brat (in print) should mother call.

I cast thee by as one unfit for light,

Thy Visage was so irksome in my sight,

Yet being mine own, at length affection would

Thy blemishes amend, if so I could.

I wash'd thy face, but more defects I saw,

And rubbing off a spot, still made a flaw.

I stretcht thy joints to make thee even feet,

Yet still thou run'st more hobbling than is meet.

In better dress to trim thee was my mind,

But nought save home-spun Cloth, i' th' house I find.

In this array, 'mongst Vulgars mayst thou roam.

In Critics' hands, beware thou dost not come,

And take thy way where yet thou art not known.

If for thy Father askt, say, thou hadst none;

And for thy Mother, she alas is poor,

Which caus'd her thus to send thee out of door. 
LA AUTORA A SU LIBRO

Tú, deforme vástago de mi débil mente que tras nacer a mi lado te quedaste hasta que, arrancado de ahí por mis amigos, más fieles que prudentes, quienes sin pudor te mostraron por doquier ante todos los ojos y en harapos te pusieron, deteniéndose los pasos ante la imprenta, donde los errores no fueron corregidos (todos lo pueden ver).

Cuando apareciste no era pequeña mi vergüenza, mi errante hijo (en prensa) debía llamar a su madre, pues yo te dejé por inepto para ver la luz, tu rostro me era incómodo de mirar, mas, siendo mío, el efecto, al final, corregiría tus imperfecciones, si me fuera posible. Lavé tu cara, pero veía aún más defectos, y quitándote una mancha, otra mácula más te hacía. Estiré tus miembros para que en tus pies tuvieras equilibrio, pero cojeando corrías más de lo que yo esperaba. Mi mente se dedicaba a adornarte con mejores prendas, mas nada encontré sino ropa bordada a mano por casa, cuídate pues de esta guisa de caer en manos de los críticos y coge un sendero por el que nadie te reconozca. Si preguntan por tu padre, di que no tienes; si por tu madre, en cambio, di que ella, joh!, es pobre, lo que motivó que te echara de su propia casa. 
Before the BiRTH of ONE OF HER CHILDREN All things within this fading world hath end, Adversity doth still our joys attend;

No ties so strong, no friends so dear and sweet,

But with death's parting blow is sure to meet.

The sentence past is most irrevocable,

A common thing, yet oh, inevitable.

How soon, my Dear, death may my steps attend.

How soon't may be thy lot to lose thy friend,

We both are ignorant, yet love bids me

These farewell lines to recommend to thee,

That when that knot's untied that made us one,

I may seem thine, who in effect am none.

And if I see not half my days that's due,

What nature would, God grant to yours and you;

The many faults that well you know

I have Let be interred in my oblivious grave;

If any worth or virtue were in me,

Let that live freshly in thy memory

And when thou feel'st no grief, as I no harms,

Yet love thy dead, who long lay in thine arms.

And when thy loss shall be repaid with gains

Look to my little babes, my dear remains.

And if thou love thyself, or loved'st me,

These O protect from step-dame's injury.

And if chance to thine eyes shall bring this verse,

With some sad sighs honour my absent hearse;

And kiss this paper for thy love's dear sake,

Who with salt tears this last farewell did take. 
ANTE EL NACIMIENTO DE UNO DE SUS HIJOS

Todo tiene fecha de caducidad en este mundo mortal, por nuestras alegrías aún nos acecha la adversidad; no hay vínculos tan fuertes ni amigos que se amen tiernamente que no esperen reunirse tras el duro golpe de la muerte. La sentencia del pasado es ya irrevocable, algo común a todos, pero, jay!, inevitable. Cuán pronto, amado mío, cercenará mis pasos la muerte. Cuán pronto sufrirás la desgraciada pérdida de tu amiga, ambos somos ignorantes, mas el amor me apremia a encomendarte estas breves líneas de despedida, que cuando se deshaga el nudo que fuerte nos unía, pueda yo parecer tuya, pues en realidad no soy nada. $Y$ si no contemplo la mitad de mis días pasados,

lo que natura haría, que Dios te lo conceda a ti y a los tuyos; los muchos defectos que tú bien sabes que me afean queden bien enterrados en mi olvidada tumba; y si alguna virtud o valor me adornaran, deja que vivan perennes en tu memoria y, cuando ya no sientas como yo la aflicción, ama aún a tu muerta, que largo tiempo has abrazado. $Y$ cuando ya tus pérdidas se salden con ganancias, mira por mis pequeños, mi herencia más preciada. $Y$ si a ti mismo te amas, o me amas a mí, protégelos de las agresiones de una madrastra. $Y$ si el azar pone ante tus ojos estos versos, con tristes suspiros honra mis ausentes pompas fúnebres; y besa este papel en honor a tu amor querido, que con saladas lágrimas te dedica este postrer adiós. 
BY NIGHT WHEN OTHERS SOUNDLY SLEPT

By night when others soundly slept

And hath at once both ease and Rest,

My waking eyes were open kept

And so to lie I found it best.

I sought him whom my Soul did Love,

With tears I sought him earnestly.

He bow'd his ear down from Above.

In vain I did not seek or cry.

My hungry Soul he fill'd with Good;

$\mathrm{He}$ in his Bottle put my tears,

My smarting wounds washt in his blood,

And banisht thence my Doubts and fears.

What to my Saviour shall I give

Who freely hath done this for me?

I'll serve him here whilst I shall live

And Loue him to Eternity

POR LA NOCHE, MIENTRAS LOS OTROS DORMÍAN

Por la noche mientras los otros dormían

y al tiempo descanso y sosiego hallaban, mis ojos abiertos sin sueño estaban

y seguir tendido mejor creía

Busqué entonces a Aquél a Quien amaba, con lágrimas lo hice y con empeño.

Su oído vino a prestarme mi Dueño. No Lo busqué en vano ni Lo lloraba.

Mi alma ansiosa de bienes Él colmó; en su Botella vertió mi llorar, mis heridas con su Sangre lavó, borrando mi temor y mis dudas.

¿Qué puedo yo dar a mi Salvador, que tan generoso ha sido conmigo? En la tierra siempre estaré con El y por siempre seré su servidor. 
DELIVERANCE FROM A FIT OF FAINTING Worthy art Thou, O Lord, of praise, But ah! It's not in me.

My sinking heart I pray Thee raise So shall I give it Thee.

My life as spider's webb's cut off, Thus fainting have I said,

And living man no more shall see But be in silence laid.

My feeble spirit Thou didst revive, My doubting Thou didst chide, And though as dead mad'st me alive, I here a while might 'bide.

Why should I live but to Thy praise? My life is hid with Thee.

O Lord, no longer be my days Than I may fruitful be.

RECUPERACIÓN DE UN DESVANECIMIENTO Te mereces, Señor, las alabanzas, mas, jay!, no me salen de dentro. Te ruego que levantes mi triste corazón, así puedo entregártelo.

Es mi vida cual tela de araña que está rota, así, desvanecida, la expreso, y a hombre vivo alguno ya volveré a ver sino postrada en el silencio.

Pudiste levantar a mi febril espíritu, y por dudar me amonestaste, $y$, aunque vivo como si estuviera muerta, aquí puedo quedarme durante algún tiempo.

¿Por qué vivir debiera si no es para alabarte? Mi vida en ti se esconde.

¡Oh, Señor!, no alargues más mis días Si no puedo dar frutos. 
DELIVERANCE FROM ANOTHER SORE FIT In my distress I sought the Lord

When naught on earth could comfort give, And when my soul these things abhorred, Then, Lord, Thou said'st unto me, "Live."

Thou knowest the sorrows that I felt; My plaints and groans were heard of Thee, And how in sweat I seemed to melt Thou help'st and Thou regardest me.

My wasted flesh Thou didst restore, My feeble loins didst gird with strength, Yea, when I was most low and poor, I said I shall praise Thee at length.

What shall I render to my God

For all His bounty showed to me?

Even for His mercies in His rod, Where pity most of all I see.

My heart I wholly give to Thee;

O make it fruitful, faithful Lord.

My life shall dedicated be

To praise in thought, in deed, in word.

Thou know'st no life I did require Longer than still Thy name to praise, Nor ought on earth worthy desire, In drawing out these wretched days.

Thy name and praise to celebrate, $\mathrm{O}$ Lord, for aye is my request.

$O$ grant I do it in this state,

And then with Thee, which is the best. 
RECUPERACIÓN DE OTRO DESVANECIMIENTO DOLOROSO En mi tribulación busqué ferviente a Dios cuando nada en la tierra podía contentarme y cuando mi alma hastiada aborrezca ya todo,

entonces, Señor, a mí vienes y dices: "Vive". Tú sabes cuántas penas he padecido yo; mis quejas y lamentos por Ti fueron oídas, cómo de sudor me encontraba anegado cuando Tú me auxiliaste y cuando me aceptaste.

Mi carne pecadora viniste a restaurar, mis débiles entrañas fuerte y firme abrazaste, sí, cuando me encontraba más caída y más mísera prometí de por vida siempre a Dios alabar.

¿Cómo habré de pagar a tan generoso Dios por todas esas dádivas con que me ha regalado? Hasta por sus mercedes desde su santa vara, donde vislumbrar puedo su divina piedad.

Mi corazón Te entrego humilde y sin reserva; ioh, haz que sea fructífero, oh Tú fiel Señor! A ti la vida entera dedicaré sin óbice para ensalzarte con obras, palabra y pensamiento.

Tú bien sabes que vida alguna he requerido más larga con el fin de ensalzar tu gran nombre, ni debía en esta tierra desear que sea mérito que lleguen ya a término estos días tan míseros.

Para celebrar tu nombre y tus alabanzas, Oh Señor, pues positiva es mi respuesta. Concédeme que lo haga en este estado, y luego contigo, que es lo mejor. 
UPON SOME DISTEMPER OF BODY

In anguish of my heart replete with woes,

And wasting pains, which best my body knows,

In tossing slumbers on my wakeful bed,

Bedrenched with tears that flowed from mournful head,

Till nature had exhausted all her store,

Then eyes lay dry, disabled to weep more;

And looking up unto his throne on high,

Who sendeth help to those in misery;

He chased away those clouds and let me see

My anchor cast i' th' vale with safety.

He eased my soul of woe, my flesh of pain,

and brought me to the shore from troubled main.

\section{SOBRE LA INDISPOSICIÓN DEL ALMA}

En mi alma acongojada de tribulación llena,

y estéril sufrimiento, que mi cuerpo conoce,

en agitados sueños víctima del insomnio,

bien empapada en lágrimas que brotaban del alma,

hasta que ya natura todas las agotara,

y mis ojos ya secos, incapaces de lloros;

y mirando a su trono asentado en lo alto,

de Aquél que mandó ayuda a los menesterosos;

Él disipó las nubes y me dejó mirar

mi ancla bien segura en el valle clavada.

Él mi alma alivió de aflicción y dolores

y me llevó a la orilla de un mar tempestuoso. 
AN EPITAPH

On my dear and ever honoured Mother

Mrs. Dorothy Dudley,

Who deceaded Decemb. 27. 1643. and of her age, 61:

Here lies

A worthy matron of unspotted life,

A loving mother and obedient wife,

A friendly neighbor, pitiful to poor,

Whom oft she fed, and clothed with her store;

To servants wisely aweful, but yet kind,

And as they did, so they reward did find:

A true instructor of her family,

The which she ordered with dexterity,

The public meetings ever did frequent,

And in her closest constant hours she spent;

Religious in all her words and ways,

Preparing still for death, till end of days:

Of all her children, children lived to see,

Then dying, left a blessed memory.

EPITAFIO A SU MADRE

Aquí yace

una digna madre de familia de vida incólume, una amorosa madre y una obediente esposa, una cordial vecina, piadosa con los pobres, a los que con frecuencia alimentó y dio ropa; con prudencia a los criados con humildad ordenaba, $y$, al de este modo hacerlo, su recompensa hallaban: verdadera instructora de toda su familia, a la que dirigía con una gran destreza, con frecuencia ideaba reuniones amistosas, extrayendo ese tiempo de sus horas de asueto; muy religiosa en todas sus palabras y modos, preparando en silencio sus días hasta la muerte: de sus vástagos todos, a los que vivir vio, cuando murió luego, dejó una santa memoria. 
HER FATHER'S EPITAPH

Within this tomb a patriot lies

That was both pious, just and wise,

To truth a shield, to right a wall,

To sectaries a whip and maul,

A magazine of history,

A prizer of good company

In manners pleasant and severe

The good him loved, the bad did fear,

And when his time with years was spent

In some rejoiced, more did lament.

1653, age 77

EPITAFIO A SU PADRE

Dentro de esta tumba reposa un patriota

que fue, al mismo tiempo, tan justo como sabio,

la verdad protegiendo, acotando el derecho,

fustigando al sectario y también vapuleándolo;

un hacedor de historia,

un perfecto comparsa

en modo fino, austero:

los buenos lo amaban, los malos lo temían,

y cuando con los años su tiempo ya expiró

a algunos alegró, muchos lo lamentaron.

1653, tenía 77 años 
THE FLESH AND THE SPIRIT ${ }^{7}$

In secret place where once I stood

Close by the Banks of Lacrim flood,

I heard two sisters reason on

Things that are past and things to come.

One Flesh was call'd, who had her eye

On worldly wealth and vanity;

The other Spirit, who did rear

Her thoughts unto a higher sphere.

"Sister," quoth Flesh, "what liv'st thou on

Nothing but Meditation?

Doth Contemplation feed thee so

Regardlessly to let earth go?

Can Speculation satisfy

Notion without Reality?

Dost dream of things beyond the Moon

And dost thou hope to dwell there soon?

Hast treasures there laid up in store

That all in th' world thou count'st but poor?

Art fancy-sick or turn'd a Sot

To catch at shadows which are not?

Come, come. I'll show unto thy sense,

Industry hath its recompence.

What canst desire, but thou maist see

True substance in variety?

Dost honour like? Acquire the same,

As some to their immortal fame;

And trophies to thy name erect

Which wearing time shall ne'er deject.

For riches dost thou long full sore?

Behold enough of precious store.

Earth hath more silver, pearls, and gold

Than eyes can see or hands can hold.

Affects thou pleasure? Take thy fill.

Earth hath enough of what you will.

Then let not go what thou maist find

For things unknown only in mind."

\footnotetext{
${ }^{7}$ Poema que pone de relieve las luchas internas de la autora para aceptar la religión puritana, en el que la carne es su visión religiosa de inicio, y el espíritu la que finalmente adoptaría.
} 
LA CARNE Y EL ESPÍRITU

En el lugar secreto donde una vez estuve cerrado por los bancos inundados de lágrimas, oí a dos hermanas razonar sobre cosas pasadas y futuras.

A una llamaron carne, pues sólo se fijaba en toda la riqueza y vanidad del mundo; la otra, llamada Espíritu, pretendía elevar todos sus pensamientos a una esfera más alta. "Hermana", dijo Carne, "¿por qué vives tan sólo de la Meditación?

¿Acaso te alimenta la Contemplación como para poder de la tierra apartarte? ¿Tu Especulación puede llegar a subsistir sin tener nada en cuenta la Realidad del mundo? ¿Soñar con esas cosas más allá de la Luna te puede hacer que esperes el habitarla pronto? ¿Tienes allí tesoros almacenados para que al llegar a este mundo dejes ya de ser pobre? ¿Qué arte de fantasía senil convence a un Tonto para poder coger las sombras que no existen? Ven, ven. Mostraré a tus sentidos, que la Industria tiene también su recompensa. ¿Qué puedes desear, sino el poder ver la auténtica esencia en la diversidad? ¿Te gustan los honores? Hazlos que sean tuyos, como hacen algunos para su fama eterna; $y$ los trofeos que eleven tu nombre a la gloria nunca el paso del tiempo rechazarlos podrá. ¿Anhelas las riquezas de una forma acuciante? Contempla largo tiempo su precioso almacén. La Tierra tiene más plata, perlas y oro del que verán tus ojos o sostener tus manos. ¿Te produce placer? Coge lo que te guste. La Tierra tiene más de lo que tú tendrás. Así pues, no te dejes ir en busca de cosas ignotas que tan solo se hallan en tu mente. 
SPIRIT

Be still, thou unregenerate part,

Disturb no more my settled heart,

For I have vow'd (and so will do)

Thee as a foe still to pursue,

And combat with thee will and must

Until I see thee laid in th' dust.

Sister we are, yea twins we be,

Yet deadly feud 'twixt thee and me,

For from one father are we not.

Thou by old Adam wast begot,

But my arise is from above,

Whence my dear father I do love.

Thou speak'st me fair but hat'st me sore.

Thy flatt'ring shews I'Il trust no more.

How oft thy slave hast thou me made

When I believ'd what thou hast said

And never had more cause of woe

Than when I did what thou bad'st do.

I'll stop mine ears at these thy charms

And count them for my deadly harms.

Thy sinful pleasures I do hate,

Thy riches are to me no bait.

Thine honours do, nor will I love,

For my ambition lies above.

My greatest honour it shall be

When I am victor over thee,

And Triumph shall, with laurel head,

When thou my Captive shalt be led.

How I do live, thou need'st not scoff,

For I have meat thou know'st not of.

The hidden Manna I do eat;

The word of life, it is my meat.

My thoughts do yield me more content

Than can thy hours in pleasure spent.

Nor are they shadows which I catch,

Nor fancies vain at which I snatch

But reach at things that are so high,

Beyond thy dull Capacity.

Eternal substance I do see

With which inriched I would be.

Mine eye doth pierce the heav'ns and see 
What is Invisible to thee.

My garments are not silk nor gold,

Nor such like trash which Earth doth hold,

But Royal Robes I shall have on,

More glorious than the glist'ring Sun.

My Crown not Diamonds, Pearls, and gold,

But such as Angels' heads infold.

The City where I hope to dwell,

There's none on Earth can parallel.

The stately Walls both high and trong

Are made of precious Jasper stone,

The Gates of Pearl, both rich and clear,

And Angels are for Porters there.

The Streets thereof transparent gold

Such as no Eye did e're behold.

A Crystal River there doth run

Which doth proceed from the Lamb's Throne.

Of Life, there are the waters sure

Which shall remain forever pure.

Nor Sun nor Moon they have no need

For glory doth from God proceed.

No Candle there, nor yet Torch light,

For there shall be no darksome night.

From sickness and infirmity

Forevermore they shall be free.

Nor withering age shall e're come there,

But beauty shall be bright and clear.

This City pure is not for thee,

For things unclean there shall not be.

If I of Heav'n may have my fill,

Take thou the world, and all that will." 


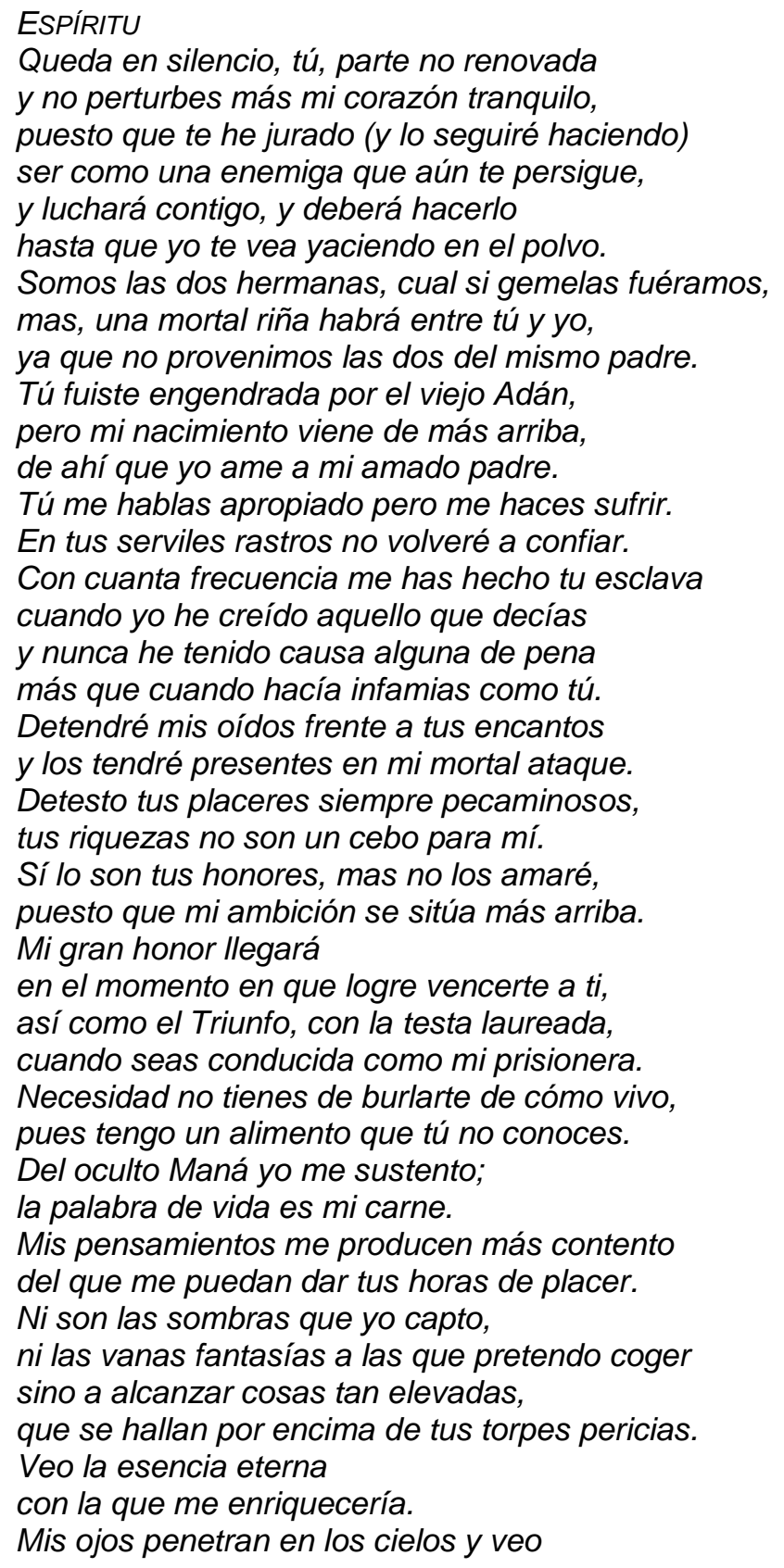


aquello que para ti es invisible.

Mis ropajes no son de seda ni de oro,

ni harapos que la Tierra pueda soportar, sino que llevo ropajes reales,

más gloriosos que el Sol radiante.

Mi corona no es de diamantes, perlas y oro, sino la que portan las testas de los Ángeles.

La ciudad en la que ansío habitar,

no puede ser comparada con nada terrenal.

Las murallas son altas y fuertes

y están hechas de piedras preciosas de jaspe,

las puertas de perlas, ricas y perfectas,

y los Ángeles son sus guardianes.

Las calles son de oro tan transparente

como el que ningún ojo puede contemplar.

Corre por allí un río de cristal

que emana del Trono del Cordero.

Hay aguas seguras de vida

que permanecerán puras para siempre.

No necesitarán Sol ni Luna

puesto que la gloria procede de Dios.

No hay velas, ni antorchas de Luz,

puesto que la noche no es oscura.

De enfermedades y dolencias

estarán libres para siempre.

La edad marchita nunca la afectará,

sino que la belleza será espléndida y relumbrante.

Esta ciudad pura no es para ti,

puesto que allí no habrá cosas sucias.

Si yo del cielo puedo estar repleta,

escoge tú el mundo, y todo lo que desees". 
The Prologue

To sing of wars, of captains, and of kings,

Of cities founded, commonwealths begun,

For my mean pen are too superior things:

Or how they all, or each, their dates have run;

Let poets and historians set these forth,

My obscure lines shall not so dim their work.

But when my wondering eyes and envious heart

Great Bartas' sugared lines do but read o'er,

Fool I do grudge the Muses did not part

'Twixt him and me that overfluent store;--

A Bartas can do what a Bartas will,

But simple I according to my skill.

From school-boys tongues no rhetoric we expect, Nor yet a sweet consort from broken strings,

Nor perfect beauty where's a main defect:

My foolish, broken, blemished Muse so sings;

And this to mend, alas, no art is able,

'Cause nature made is so, irreparable.

Nor can I, like that fluent, sweet-tongued Greek

Who lisped at first, in future times speak plain;

By art he gladly found what he did seek--

A full requitl of his striving pain.

Art can do much, but this maxim's most sure:

A weak or wounded brain admits no cure.

I am obnoxious to each carping tongue

Who says my hand a needle better fits.

A poet's pen all scorn I should thus wrong;

For such despite they cast on female wits,

If what I do prove well, it won't advance--

They'll say it was stolen, or else it was by chance.

But shure the ancient Greeks were far more mild, Else of our sex why feignéd they those Nine,

And Posey made Calliope's own child?

So 'mongst the rest they placed the Arts Divine.

But this weak knot they will full soon untie--

The Greeks did naught but play the fools and lie. 
Let Greeks be Greeks, and women what they are.

Men have precenency, and still excell.

It is but vain unjustly to wage war,

Men can do best, and women know it well.

Preëminence in all and each is yours--

Yet grant some small acknowledgement of ours.

And oh, ye high flownquills that soar the skies, And ever with your prey still catch your praise,

If e'er you deign these lowly lines your eyes,

Give thyme or parsley wreath; I ask no bays.

This mean and unrefined ore of mine

Will make your glistening gold but more to shine. 


\begin{abstract}
EL PRÓLOGO
Temas muy altos son para mi humilde pluma cantar a capitanes a los reyes y guerras, de ciudades fundadas, de estados iniciados, o cómo todos ellos han pasado sus días; dejemos que poetas e historiadores narren, no menguará mi pluma oscura su valor.
\end{abstract}

Mas cuando mi alma llena de admiración y envidia no hagan sino leer los versos del gran Bartas, me quejaré a las Musas de no haber repartido entre él y yo ese cúmulo de elocuencia; Bartas puede hacer todo lo que a Bartas le plazca, mas yo he de resignarme a obrar por mis destrezas.

De los académicos no esperamos retórica, ni un dulce Consorte de unas cuerdas rotas, ni visible defecto de sublime belleza: mi necia, torpe Musa imperfecta así canta; y no hay Arte que pueda, no, tal cosa ya enmendar porque lo hizo Natura así de irreparable.

Ni tenga yo la afluencia, de la voz dulce griega que hablaba con defecto, y ahora habla correcto; por 'inspiratio' alegre halló lo que buscaba. Una pena completa de su dolor constante. El arte satisface, pero dice la máxima:

Cerebro herido o débil no admite cura alguna.

Aborrezco esas lenguas que sólo lanzan críticas que dicen que a mi mano sienta mejor la aguja. La pluma del poeta desprecia lo que yo hago, por todo ese desprecio que hacia la mujer lanzan. Si lo que yo bien pruebo no seguirá adelante, dirán que ello es robado, o que fue mera suerte.

Mas los griegos, seguro, fueron aún más afables, Mas no de nuestro sexo. ¿A qué fingir que ellas, y la poesía hicieron la hija de Calíope?

Así, entre los demás colocaron las Artes. Mas, este débil nudo pronto desatarían, los Griegos nada hicieron sino fingir patéticos 
Que los griegos sean griegos, las mujeres como son.

Los hombres son primero, y aún destacan más;

no es sino algo injusto y vano hacer la guerra.

Los hombres son mejores, las mujeres lo saben.

La Superioridad en cada cosa es tuya;

pero al menos concédenos un reconocimiento.

Oh vosotras las plumas que voláis por el cielo y siempre con la presa capturan alabanzas,

si desdeñar quisieran vuestros ojos los versos, dales una guirnalda de tomillo o perejil,

no de laurel, pues este bruto material mío

no hará sino que el oro brille más en tu mano. 


\section{As WeARY PILGRIM}

As weary pilgrim, now at rest,

Hugs with delight his silent nest

His wasted limbs, now lie full soft

That mirey steps, have trodden oft,

Blesses himself to think upon

His dangers past, and travails done.

The burning sun no more shall heat

Nor stormy rains on him shall beat.

The briars and thorns no more shall scratch,

Nor hungry wolves at him shall catch.

He erring paths no more shall tread,

Nor wild fruits eat, instead of bread.

For waters cold he doth not long

For thirst no more shall parch his tongue.

No rugged stones his feet shall gall,

Nor stumps nor rocks cause him to fall.

All cares and fears he bids farwell

And means in safety now to dwell.

A pilgrim I, on earth, perplexed

With sins wth cares and sorrows vext,

By age and pains brought to decay,

And my clay house mould'ring away.

Oh, how I long to be at rest

And soar on high among the blest.

This body shall in silence sleep,

Mine eyes no more shall ever weep,

No fainting fits shall me assail,

Nor grinding pains my body frail,

With cares and fears ne'er cumb'red be

Nor losses know, nor sorrows see.

What though my flesh shall there consume,

It is the bed Christ did perfume,

And when a few yeares shall be gone,

This mortal shall be clothed upon.

A corrupt carcass down it lays,

A glorious body it shall rise.

In weakness and dishonour sown,

In power 'tis raised by Christ alone.

Then soul and body shall unite

And of their Maker have the sight.

Such lasting joys shall there behold 
As ear ne'er heard nor tongue e'er told.

Lord make me ready for that day,

Then come, dear Bridegroom, come away.

COMO UN PEREGRINO FATIGADO 8

Cual peregrino hastiado, ya en reposo,

se abraza gustoso a su suave nido.

Sus molidas piernas que han recorrido

caminos de fango, ya en paz descansan.

A sí mismo se bendice al pensar

en mil peligros y esfuerzos pasados.

El sol ardiente no lo quemará

ni sobre él caerán más rayos y truenos.

No lo lastimarán zarzas ni brezos,

ni lobos hambrientos lo atacarán.

No pisará más senderos errantes,

ni comerá otras frutos sino pan.

No ansiará tanto beber agua fría,

pues su lengua la sed no secará.

No herirán las duras piedras sus pies, ni en troncos ni rocas tropezará.

A toda cuita y miedo dice adiós y desea seguro ahora morar.

Peregrino Yo, en la tierra, perplejo de pecados, penas y aflicción lleno, agobiado por el dolor, ya viejo,

mi casa de barro se desmorona.

¡Oh!, cuánto deseo ya descansar y subir muy alto con los bendecidos.

Este cuerpo dormirá ya en silencio, mis ojos nunca más llorarán,

no me asaltará un desvanecimiento,

ni a mi frágil cuerpo un padecimiento,

con cuidados y temores que nunca han sido superados.

Ni la pérdida conoce, ni el arrepentimiento ve.

Qué pensó mi carne ahí al consumir,

es la cama que Cristo perfumó,

y cuando hayan pasado algunos años,

\footnotetext{
8 "As Weary Pilgrim" es una muestra real del modo en que la autora expresa el cansancio que los humanos experimentan a veces ante las adversidades, así como la esperanza del reposo en la otra vida; el poema es una especie de plasmación de las penas e inquietudes ("trash") de los primeros puritanos.
} 
este mortal estará vestido.

Un cadáver corrupto yace,

un cuerpo lleno de gloria se elevará.

Arraigado en la debilidad y el deshonor, por Cristo poderosamente será elevado.

Entonces cuerpo y alma se unirán

y de su Creador tomarán la imagen.

Tales alegrías serán contempladas

como ningún oído haya oído ni ninguna lengua haya dicho.

¡Oh Señor!, prepárame para ese día,

entonces ven, amado novio, vete.

\section{CONCLUSIÓN}

La poesía de Anne Bradstreet, a pesar del tiempo transcurrido desde su gestación, sigue llegando al corazón de los lectores que aprecian valores tan tradicionales como la importancia de la familia ("Verses upon the burning of her house..."), por medio de la expresión de los sentimientos más recónditos del alma humana, expresados con un consumado talento poético. Es mucho más que una "Puritan poet", es una poetisa de primer orden en la que el lenguaje y la imaginería son muy directos y sencillos, consiguiendo siempre transmitir al lector una impresión de calidez, al tiempo que lo devuelve a tiempos pretéritos, en los que puede ensoñar los acontecimientos que vivieron los peregrinos en New England como si los contemplaran de primera mano. El lector, dado el lenguaje tan hondo y comprensible que se encuentra en la lectura de estos poemas, no puede evitar el identificarse con ellos, mostrando una simpatía y compresión total hacia la obra de esta mujer, culta, sencilla y sensible, cuyo reconocimiento en el mundo literario (no sólo de habla inglesa) va creciendo a medida que su obra alcanza una difusión más extensa.

\section{REFERENCIAS BIBLIOGRÁFICAS}

a) Ediciones de sus obras

BRADSTREET, Anne, The Tenth Muse Lately Sprung up in America: Or Several Poems, Compiled with Great Variety of Wit and Learning, Full of Delight, 1650.

Several Poems, Compiled with Great Variety of Wit and Learning, Full of Delight, edited by John Foster, Boston, 1678.

Several Poems, Compiled with great Variety of Wit and Learning, full of Delight (Reprinted from the second Edition), 1758. 
, The Works of Anne Bradstreet in Prose and verse, edited by John Harvard Ellis, Charlestown, Abram E. Cutter, 1867.

, The Works of Mrs Anne Bradstreet (1612-1672) Together with Her Prose remains, ed. E. E. Hopkins, 1897.

The Poems of Anne Bradstreet in Prose and Verse, ed. J. H.

The Works of Anne Bradstreet, Edited by Jeannine Hensley with foreword by Adrienne Rich. Harvard University Press, 1967.

, The Works of Anne Bradstreet, Ed. Robert Hensley, Cambridge, Mass.: The Belknap Press of Harvard University Press, 1967.

The Several Poems Poetry. The Complete Works of Anne Bradstreet, Eds. Joseph R. McElrath, Jr. and Allan P. Robb, Boston, Twayne Publishers, 1981.

The Tenth Muse Poetry. The Complete Works of Anne Bradstreet. Eds. Joseph R. McElrath and Allan P. Robb, Boston, Twayne Publishers, 1981.

b) Estudios

ARNER, Robert D., "The Structure of Anne Bradstreet's Tenth Muse". En: Discoveries \& Considerations: Essays on Early American Literature \& Aesthetics Presented to Harold Jantz, ed. Calvin Israel, Albany, State University of New York Press, 1976, pp. 46-66.

BLACKSTOCK, Carrie Galloway, "Anne Bradstreet and Performativity: SelfCultivation, Self- Deployment". En: Early American Literature 32.3 (1997): 222-48.

BRANDT, Ellen B., "Anne Bradstreet: The Erotic Component in Puritan Poetry". En: Women's Studies 7.1-2, 1980, pp. 39-53.

CALdWELL, Patricia, "Why Our First Poet Was a Woman: Bradstreet and the Birth of an American Poetic Voice". En: Prospects: An Annual Journal of American Cultural Studies 13, 1988, pp. 1-35.

CAmpBeLl, Helen Stuart, Anne Bradstreet and Her Time, Boston, 1891.

CoWel, Pattie; StAnFord, Ann (eds.), Critical Essays on Anne Bradstreet. Boston: G. K. Hall, 1983.

CRAIG, Raymond A., "Singing with Grace: Allusive Strategies in Anne Bradstreet's 'New Psalms'". En: Studies in Puritan American Spirituality 1, 1990, pp.148-69.

A Concordance to the Complete Works of Anne Bradstreet, two volumes. Lewiston, New York: Mellen, 2000.

DALY, Robert, "Powers of Humility and the Presence of Readers in Anne Bradstreet and Phillis Wheatley". En: Studies in Puritan American Spirituality 4, 1993, pp.1-24.

Dolle, Raymond F., Anne Bradstreet: A Reference Guide, G. K. Hall \& Co. Boston, Massachussets, 1990. 
DORIANI, Beth M., "'Then Have I... Said With David': Anne Bradstreet's Andover Manuscript Poems and the Influences of the Psalm Tradition". En: Early American Literature 24.1, 1989, pp. 52-69.

EATON, Sara, "Anne Bradstreet's 'Personal' Protestant Poetics". En: Women's Writing 4.1, 1997, pp. 57-71.

EBERWEIN, Jane Donahue, "'No Rhet'ric We Expect': Argumentation in Bradstreet's 'The Prologue'". En: Early American Literature 16.1, 1981, pp. 19-26.

Gordon, Charlotte, Mistress Bradstreet: The Untold Life of America's First Poet, New York: Little, Brown \& Company, 2005.

HESFORD, Walter, "The Creative Fall of Bradstreet and Dickinson". En: Essays in Literature 14.1, 1987, pp. 81-91.

IRVIN, William J., "Allegory and Typology 'Imbrace and Greet': Anne Bradstreet's 'Contemplations'". En: Early American Literature 10, 1975, pp. 30-46.

JED, Stephanie, "The Tenth Muse: Gender, Rationality, and the Marketing of Knowledge". En: Women, 'Race,' and Writing in the Early Modern Period, eds. Margo Hendricks and Patricia Parker. London, Routledge, 1994, pp. 195-208.

MARTIN, Wendy, "Anne Bradstreet's Poetry: A Study of Subversive Piety". En: Shakespeare's Sisters: Feminist Essays on Women Poets, ed. Sandra Gilbert, and Susan Gubar, Bloomington, Indiana U P, 1978. An American Triptych: Anne Bradstreet, Emily Dickinson, Adrienne Rich. Chapel Hill, University of North Carolina Press, 1984.

MATHer, Cotton, Magnalia Christi Americana, Ecclesiastical History of New England, from its First Planting in the year 1620, Unto the Year of Our Lord, 1698, In Seven Books, New Haven, CT. 1820 edition.

MEANY, Birgit, "The Contemplative Art of Anne Bradstreet's 'Contemplations'.", 1993, pp. 71-103.

MEHLER, Carol R., "Anne Bradstreet's House Fire: The Careless Maid and Careful God". En: Studies in Puritan American Spirituality, 1995, pp. 6371.

MoRISON, Samuel Eliot, Builders of the Bay Colony. A Classics Edition. Boston: Northeastern University Press, 1930.

NicolaY, Theresa Freda, Gender Roles, Literary Authority, and Three American Women Writers: Anne Dudley Bradstreet, Mercy Otis Warren, Margaret Fuller Ossoli, New York: Peter Lang, 1995.

OSER, Lee, "Almost a Golden World: Sidney, Spenser, and Puritan Conflict in Bradstreet's 'Contemplations'". En: Renascence: Essays on Value in Literature 52.3, 2000, pp. 187-202. 
REES, Michael D., "The Prologues of Edward Taylor and Anne Bradstreet: A Psychoanalytic Reading". En: Journal of Evolutionary Psychology 18.1-2, 1997, pp. 5-14.

REQUA, Kenneth A., "Anne Bradstreet's Use of Du Bartas in 'Contemplations'". En: Essex Institute Historical Collections 110, 1974, pp. 64-69.

"Anne Bradstreet's Poetic Voices". En: Early American Literature 9, 1974, pp. 3-18.

RichaRDSON, Robert D. Jr., "The Puritan Poetry of Anne Bradstreet". En: Critical Essays on Anne Bradstreet, Ed. Pattie Cowell, and Ann Stanford. Boston: G. K. Hall, 1983.

Rosenfeld, Alvin H., "Anne Bradstreet's 'Contemplations': Patterns of Form and Meaning". En: New England Quarterly 43, 1970, pp. 79-96.

ROSENMEIER, Rosamund R., "'Divine Translation': A Contribution to the Study of Anne Bradstreet's Method in the Marriage of Poems". En: Early American Literature 12, 1977, pp. 121-35.

Anne Bradstreet Revisited. Boston: Twayne Publishers, 1991.

SALSKA, Agnieszka, "Puritan Poetry: Its Public and Private Strain". En: Early American Literature 19 (2), 1984, pp. 107-121.

SALTMAN, Helen, "'Contemplations': Anne Bradstreet's Spiritual Autobiography". En: Critical Essays on Anne Bradstreet, Eds. Pattie Cowell and Ann Stanford. Crit. Essays on Amer. Lit. Boston: Hall, 1983, pp. 226-237.

SARGENT, Ritamarie, "Poetry and the Puritan Faith: The Elegies of Ann Bradstreet and Edward Taylor". En: A Salzburg Miscellany: English and American Studies 1964-1984. Uni. Salzburg, Inst. fur Anglistik \& Amerikanistik, 1984.

SCHEICK, William, "Logonomic Conflict in Anne Bradstreet's 'A Letter to Her Husband'”. En: Essays in Literature 21 (2), 1994, pp. 166-175.

SCHWEITZER, Ivy, "Anne Bradstreet Wrestles with the Renaissance". En: Early American Literature 23 (3), 1988, pp. 291-312.

The Work of Self-Representation: Lyric Poetry in Colonial New England, Chapel Hill: University of North Carolina Press, 1991.

SHUFFELTON, Frank, "Anne Bradstreet's Contemplations". En: Gardens, and the Art of Memory, 1993, pp. 25-43.

StANFORD, Ann, Anne Bradstreet, the Wordly Puritan: An Introduction to Her Poetry. New York: Franklin, 1974.

SWEET, Timothy, "Gender, Genre, and Subjectivity in Anne Bradstreet's Early Elegies". En: Early American Literature 23 (2), 1988, pp.152174. 
WALKER, Cheryl, "Anne Bradstreet: A Woman Poet". En: Critical Essays on Anne Bradstreet, eds. Pattie Cowell and Ann Stanford. Boston: Hall, 1983, pp. 254-261.

WESS, Robert C., "Religious Tension in the Poetry of Anne Bradstreet". En: Christianity and Literature 25 (2), 1976, pp. 30-36.

WHITE, Peter (ed.), Puritan Poets and Poetics: Seventeenth-Century American Poetry in Theory and Practice. University Park, Pennsylvania State UP, 1985.

WILson, Douglas: Beyond Stateliest Marble: The Passionate Femininity of Anne Bradstreet, ed. George Grant, Turner Pub Co, ("Leaders in Action Series"), 2001.

WINNEBRENNER, Kimberly Cole, "Bradstreet's Emblematic Marriage". En: Studies in Puritan American Spirituality 4, 1993, pp. 45-70. 
